\title{
A STUDY TO ASSESS THE BURNOUT AMONG NURSES AT SELECTED HOSPITAL CHENNAI.

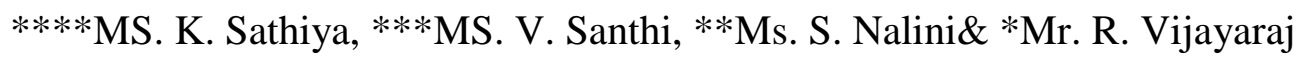

\begin{abstract}
The aim of this study was to assess the burnout among orthopedic nurses. Totally 30 sample were selected by using simple random sampling methods in orthopedic ward. The result revels that in relation to Emotional exhaustion majority 26 (87\%) of them had low level of burnout,4(13\%) had moderate level of burnout and none of them had high level of burnout. With regards to depersonalization majority $17(57 \%)$ of them $17(57 \%)$ had moderate level of burnout,13(43\%) had low level of burnout and 6(20\%) had high level of burnout. With respect to Personal achievement majority 15 (50\%) of them had high level of burnout,7(23\%) had low level of burnout and 2(7\%) had moderate level ofburnout.
\end{abstract}

Key words - Burnout, Stress, Orthopedic ward and Orthopedic Nurses

\section{INTRODUCTION}

The -burnoutllis workers reactions to the chronic stress and it is a syndrome characterized by emotional exhaustion, depersonalization, and reduced personal accomplishment in work life. The effect of burnout for an individual includes difficulty in concentration, decreased self-esteem, sleep disorders, social isolation, and alcohol or drug abuse ${ }^{1-2}$.

Workplace stress has been well documented as a. Burnout is commonly conceptualized as a multidimensional syndrome consisting of three components, emotional exhaustion, depersonalization, and reduced personal accomplishment ${ }^{3}$. Emotional exhaustion arises as emotional resources are depleted, workers feel they are no longer able to give of themselves at a psychological level. Depersonalization occurs when workers develop negative cynical attitudes and feelings about one's patients $^{4-5}$. Reduced personal accomplishment refers to the tendency to evaluate oneself negatively, particularly in regard to one's work with patients.Previous research has associated both individual and work characteristics with levels of burnout ${ }^{6}$.

\section{NEED FOR THESTUDY}

There has been much research on burnout in nurses, presumably because of the intense nature of their contact with patients ${ }^{7-8}$. This is particularly so if employees have been through difficult work changes such as organizational reform. Prior to this study being conducted, hospitals in Australia had undergone substantial organizational change. Reform of hospital environments has previously been found to negatively impact on nurses in particular as it results in restructuring and inadequate workforce numbers. Similarly, restructuring has been found to be associated with emotional distress role stress and workfamily conflict. Consequently, because the changes above have the potential to impact negatively on nurses' experiences they were perceived to be an ideal group for further study in relation toburnout ${ }^{9}$.

In addition to investigating individual characteristics (eg. age, years of experience)thatareofteninvestigatedin 
burnout research, work characteristics that were relatively specific to the nursing profession at this time (eg. where nursing qualification was gained, that is, hospital training or university based education), and overtime, were also included in the study. It was thought prudent to investigate overtime in this sample since with the reported increased workloads and decreased staff numbers it was likely that overtime may be an issue for nurses.

\section{OBJECTIVES OF THE STUDY}

1. Assess the level of burnout among Nurses

2. Associate the level of burnout with selected back groundvariables

\section{METHODOLOGY}

Evaluation approach was considered to achieve the objectives of the study. The research design adopted for this study was an descriptive, survey approach. The study was conducted in $\mathrm{G}$ block orthopaedicward sister of selected Hospital at Chennai. The target population was nurses. The accessible population was both male and female orthopedic ward sisters.both male and female orthopedic ward sisters. who fulfilled the inclusion criteria, working in the orthopaedic ward during the period of study were considered as samples. The sample consisted of 30 orthopedic ward sister. Random sampling method wasused.
Score interpretation of the tool

\begin{tabular}{|c|c|c|c|}
\hline $\begin{array}{c}\text { Level of } \\
\text { burnout }\end{array}$ & $\begin{array}{l}\text { Emotional } \\
\text { exhaustion }\end{array}$ & $\begin{array}{l}\text { Depersonaliz } \\
\text { ation }\end{array}$ & $\begin{array}{l}\text { Personal } \\
\text { achievement }\end{array}$ \\
\cline { 2 - 4 } & Total -42 & Total -42 & Total -48 \\
\hline $\begin{array}{c}\text { Low level } \\
\text { of } \\
\text { burnout }\end{array}$ & $<17$ & $<5$ & $<33$ \\
\hline $\begin{array}{c}\text { Moderate } \\
\text { level of } \\
\text { burnout }\end{array}$ & $18-29$ & $6-11$ & $34-49$ \\
\hline $\begin{array}{c}\text { High level } \\
\text { of } \\
\text { burnout }\end{array}$ & $>30$ & $>12$ & $>40$ \\
\hline
\end{tabular}

\section{Results}

\section{Frequency and percentage distribution} of background variables among Nurses ( $\mathrm{N}=30)$

With regards to age majority $27(90 \%)$ of them were in between 21-25 yrs and 3(10\%) in between 26-30 yrs. In relation to sex $23(77 \%)$ of them were female and $7(23 \%)$ were male

With respect to educational status majority $19(64 \%)$ of them were $19(64 \%)$ had diploma and 11(36\%) had B.Sc and in relation to years of experience $23(77 \%$ ) had 1-2 yrs, 6(20\%) had 3-4 yrs ofexperiences and $1(3 \%)$ had $>4$ yrs

With regards to type of family $20(67 \%)$ nurses from joint family and $10(33 \%)$ from nuclear family and in relation to marital status $23(77 \%)$ were married and $7(23 \%)$ were unmarried. 
2. Frequency and percentage distribution of level of burnout among Nurses $(\mathrm{N}=30)$

\begin{tabular}{|l|c|c|c|c|c|c|}
\hline \multirow{2}{*}{$\begin{array}{l}\text { Level of } \\
\text { burnout }\end{array}$} & \multicolumn{2}{|c|}{$\begin{array}{c}\text { Emotional } \\
\text { exhaustion }\end{array}$} & \multicolumn{2}{|c|}{ Depersonalization } & \multicolumn{2}{|c|}{$\begin{array}{c}\text { Personal } \\
\text { achievement }\end{array}$} \\
\cline { 2 - 6 } & $\begin{array}{c}\text { Frequen } \\
\text { cy }\end{array}$ & $\%$ & Frequency & $\%$ & $\begin{array}{c}\text { Freque } \\
\text { ncy }\end{array}$ & $\%$ \\
\hline $\begin{array}{l}\text { Low } \\
\text { level of } \\
\text { burnout }\end{array}$ & 26 & 87 & 7 & 23 & 13 & 43 \\
\hline $\begin{array}{l}\text { Moderat } \\
\text { e level of } \\
\text { burnout }\end{array}$ & 4 & 13 & 17 & 57 & 2 & 7 \\
\hline $\begin{array}{l}\text { High } \\
\text { level of } \\
\text { burnout }\end{array}$ & 0 & 0 & 6 & 20 & 15 & 50 \\
\hline
\end{tabular}

Table 2 revealed that frequency and percentage distribution of level of burnout among Nurses.

In relation to Emotional exhaustion majority $26(87 \%)$ of them had low level of burnout, 4(13\%) had moderate level of burnout and none of them had high level of burnout.

With regard to depersonalization majority $17(57 \%)$ of them had moderate level of burnout, 13(43\%) had low level of burnout and $6(20 \%)$ had high level of burnout.

With respect to Personal achievement majority $15(50 \%)$ of them had high level of burnout, $7(23 \%)$ had low level of burnout and $2(7 \%)$ had moderate level of burnout.

3. Association of background variables with the level of burnout among Nurses (N=30) There was a significant association between sex, years of experience and marital status with the level ofburnout.

\section{CONCLUSION}

Burnout scores were remarkably high among orthopedic Nurses, with more years of experience had higher emotional exhaustion and lower Personal achievement.
The study has also highlighted the importance of working manageable hours and that increasing years of nursing experience is likely to be beneficial for the worker. Additionally, working pressured or unexpected overtime was associated with increased levels of emotional exhaustion and depersonalization indicating the need for management to be mindful of this situation occurring, particularly if foreshadowed nurse shortagescontinue.

\section{REFERENCES}

1. Aiken, L.H., Clarke, S.P., Sloane, D.M., Sochalski, J.A., Busse, R., Clarke, H., Giovannetti, P., Hunt, J., Rafferty, A.M. and Shamian, J. Nurses' reports on hospital care in five countries. Health Affairs, 20(3):4353, 2001.

2. Burke, R.J. and Greenglass, E.R. Hospital restructuring stressors, work familyconcerns and psychological well-being among nursing staff and Work and Family, 4(1):4962,2001 .

3. Buunk, B.P. and Schaufeli, W.B. Burnout: A perspective from social comparison theory. In W. Schaufeli, C. Maslach, and C. Marek (eds), Professional burnout: recent developments in theory and research(pp.53-66), 1993.

4. Washington, DC: Taylor and Francis. Demerouti, E., Bakker, A.B., Nachreiner, F. and Schaufeli, W. B. A model of burnout and life satisfaction amongst nurses. Journal of Advanced Nursing,32(2):454-464,2000. 
5. Dewe, P., Leiter, M. and Cox, T. Coping, health and organisations. New York: Taylor andFrancis,2000.

6. Evers, W., Tomic, W. and Brouwers, A. Effects of aggressive behavior and perceived self-efficacy on burnout among staff of homes for the elderly. Issues in Mental Health Nursing,22(4):439-454,2001.

7. Stordeur, S, D'hoore, W. and Vandenberghe, C. Leadership, organisational stress, andemotional exhaustion among hospital nursing staff. Journal of Advanced Nursing, 35(4):533542, 2001.

8. Swanson, V. and Power, K. Employees' perceptions oforganisational restructuring: the role of social support. Work and Stress, 15(2):161-178. 2001.

9. Maslach, C., Jackson, S.E. andLeiter, M.P. Maslach Burnout Inventory (3rd ed). Palo Alto, California: Consulting Psychologists Press Inc, 2001. 